\title{
Recent Developments on Broodstock Maturation and Reproduction of Farfantepenaeus paulensis
}

\author{
Sílvio Peixoto*, Ronaldo Olivera Cavalli and Wilson Wasielesky \\ Fundação Universidade Federal do Rio Grande; Departamento de Oceanografia; Laboratório de Maricultura; \\ C. P. 474; 96201-900; Rio Grande - RS - Brasil
}

\begin{abstract}
This paper describes the latest developments on maturation and reproduction of Farfantepenaeus paulensis in captivity, with special reference to the studies conducted during the last decade at the Laboratory of Mariculture, University of Rio Grande in southern Brazil, aiming to improve the future outlook for a sustainable nauplii production of F. paulensis. Particular emphasis has been given on the reproductive cycle, ovarian maturation, maturation and spawning systems, artificial insemination, broodstock reproductive performance and maintenance of captive broodstock.
\end{abstract}

Key words: Reproduction, maturation, Farfantepenaeus paulensis, penaeid

\section{INTRODUCTION}

The pink shrimp Farfantepenaeus paulensis has been exploited since the end of the $19^{\text {th }}$ century by artisanal fisheries in the Patos Lagoon estuary, extreme southern Brazil, but catches have declined sharply in the last 20 years causing significant impacts on the local economy (Reis and D'Incao, 2000; D'Incao and Reis, 2002). However, recent studies on $F$. paulensis culture could bring a new perspective for the shrimp market in the region. The culture of $F$. paulensis in pen enclosures within the estuarine area has been developed as an alternative for fishermen communities (Wasielesky et al., 1999; Wasielesky et al., 2001). This species has also been considered for pond culture in extreme southern Brazil as the growing season for the exotic Litopenaeus vannamei could be limited by low water temperatures (Peixoto et al., 2003a).
Worldwide expansion of shrimp farming over the last two decades is attributed mostly to the success in the production of high quality nauplii through controlled maturation and reproduction (Browdy, 1992). Several reviews on the maturation of penaeids have been published over the past few years (Bray and Lawrence, 1992; Browdy, 1992; Browdy, 1998). However, all information available on the reproduction of $F$. paulensis is dispersed in studies conducted mainly in southern Brazil at the Federal University of Rio Grande (FURG, Rio Grande, Rio Grande do Sul) and Federal University of Santa Catarina (UFSC, Florianópolis, Santa Catarina).

Since the early 80's, nauplii production of $F$. paulensis in Brazil has been based on the capture of wild broodstock in coastal waters off Santa Catarina (Marchiori and Boff, 1983; Marchiori and Cavalli, 1993). Despite their supposed advantageous performance, the unpredictable supply and high capture costs are constraining the

\footnotetext{
* Author for correspondence
} 
culture sustainability in the region. Therefore, several studies have been carried out to optimize maturation and reproduction of $F$. paulensis in captivity, especially the evaluation of domesticated broodstock as an alternative (Cavalli et al., 1997; Peixoto et al., 2002a,b; Peixoto et al., 2003b,c,d; Peixoto et al., 2004a,b). Furthermore, our research group is currently the only one working with controlled reproduction of $F$. paulensis and therefore has accumulated undeniable experience in this area during the last 20 years.

The objective of this review was to summarize the current knowledge on the maturation and reproduction of $F$. paulensis, with special reference to the studies that have been conducted during the last decade in our laboratory. This review could improve the future outlook for a sustainable nauplii production of $F$. paulensis in southern Brazil.

\section{REPRODUCTIVE AND MOLTING CYCLES}

Most shrimp species of interest for aquaculture belonged to the genus Penaeus (Dall et al., 1990), which has been recently divided by Pérez-Farfante and Kensley (1997) into several other genera based on differences in their reproductive system. $F$. paulensis is distributed from Ilhéus $\left(14^{\circ} 50^{\prime} \mathrm{S}\right)$, Brazil to Mar del Plata (38 $30^{\circ}$ 'S), Argentina (D'Incao, 1991). As most penaeids, $F$. paulensis presents two different phases in its life cycle: an oceanic one, marked by reproduction and larval development, and another represented by growth in estuarine areas (D'Incao, 1991). Although $F$. paulensis juveniles colonize annually the shallow waters of the Patos Lagoon estuary $\left(32^{\circ} \mathrm{S}\right)$ (Rio Grande do Sul, Brazil), the nearest representative adult population is found in coastal waters of Santa Catarina $\left(27^{\circ} \mathrm{S}\right)$ (Zenger and Agnes, 1977; D'Incao, 1999).

Penaeids may be separated in closed and open thelycum species, which refers to the female reproductive anatomy to store the spermatophores after mating (Dall et al., 1990). Since $F$. paulensis is a closed-thelycum species, mating takes place when males are in their intermolt period and females are recently molted (soft cuticle). Brisson (1985) described in detail the mating behavior of $F$. paulensis, which is marked by the male turning upside down below the female, rapidly rotating perpendicularly, squeezing the female and then transferring the spermatophore. After the hardening of the exoskeleton, mature females may fertilize several spawns with the sperm from one mating, but they must mate again after each ecdysis to ensure fertilized spawns during the next intermolt period because the spermatophore is lost with the exuviae (Marchiori and Boff, 1983; Marchiori, 1996). The reproductive cycle of closed thelycum species differs significantly from the open thelycum ones. For the latter, a hard-shelled female mates immediately prior to spawning and the spermatophore attached externally to the thelycum is lost after each spawn (Ogle, 1992).

Molting rates usually increase in captive maturation systems due to the acceleration of the metabolism caused by higher temperatures and the strong influence of eyestalk ablation on the endocrine control of the molting process (Dall et al., 1990). Studies on the relationship between molt cycle and reproductive performance could improve the planning of nauplii production in captivity. Reproduction of unilaterally eyestalkablated $F$. paulensis in relation to its molt cycle in a continuous water flow or a batch renewal maturation system was analyzed by Peixoto et al. (2003c). Results indicated that the intermolt period of females and males $(17.4 \pm 3.2$ and $17.8 \pm 4.6$ days, respectively), number of days between molts and first spawn $(6.9 \pm 2.8$ days $)$ and number of spawns in the intermolt period $(1.4 \pm 0.5)$, were not significantly different between the maturation systems. Additionally, results from another study indicated that the intermolt period (14.7 to 15.8 days) and the number of spawns/intermolt (1.6 to 1.7) of eyestalk-ablated $F$. paulensis females were not affected by the presence or absence of males in maturation tanks (Peixoto et al., 2004a).

\section{OVARIAN MATURATION}

Unilateral eyestalk ablation is the most common and effective way to induce ovarian maturation and spawning of many species of penaeid shrimp in captivity (Browdy, 1992). Although the endocrinological processes controlling gonad maturation in penaeids are not yet fully understood, eyestalk ablation presumably accelerates this process as it reduces the synthesis and release of the gonadal inhibitory hormone 
(GIH) from the neurosecretory complex located in the eyestalk (Dall et al., 1990; Huberman, 2000). Peixoto et al. (1998) maintained wild-caught, eyestalk ablated and unablated $F$. paulensis females under similar environmental conditions and found that ablation was essential to attain maturation and spawning rates that were high enough to sustain commercial nauplii production. Furthermore, the positive effects of eyestalk ablation in ovarian development were also observed through histological analysis of spent ovaries from unablated and ablated $F$. paulensis. Ovaries of eyestalk-ablated females presented advanced stages of oocyte development just a few hours after spawning, which indicated a comparatively faster rate of ovarian maturation in these females (Peixoto et al., 2002a).

Visual observation of females, especially the shape and color of their ovaries, has been routinely applied to evaluate the stage of maturation of penaeids under laboratory and field conditions. In captivity, accurate identification of ovarian development is necessary in order to avoid excessive handling stress and waste of fertile spawns into the tanks (Browdy, 1992). Although histological analyses have been widely used to describe ovarian maturation stages of penaeids (Tan-Fermin and Pudadera, 1989; Quinitio et al., 1993; Medina et al., 1996; Palacios et al., 1999; Ayub and Ahmed, 2002), not much information on its relationship with visual changes during ovarian development are available

As with other penaeids, the stages of ovarian maturation of $F$. paulensis have been traditionally assessed by visual observations (Marchiori and Boff, 1983; Marchiori and Cavalli, 1993; Cavalli et al., 1997; Peixoto et al., 2003b). Nevertheless, available descriptions of maturation stages for $F$. paulensis are rather conflicting since different number and types of stages have been described according to histological and visual features. For wild $F$. paulensis captured in deep-sea waters, histological classification of ovarian development described four stages (Worsmann et al., 1971), which were later confirmed through cell ultrastructure analysis (Worsmann and Sesso, 1977). On the other hand, when classification was based only on ovarian morphology and color, five (D'Incao, 1999) or six (Marchiori and Boff, 1983; Marchiori, 1996) maturation stages have been proposed.

Recently, the description of the ovarian development of $F$. paulensis relating histological sections and visual features using a chromatic scale (Pantone Matching System, Coated Simulation, Pantone, Carlstadt, NJ, USA) was reported by Peixoto et al. (2003d). Wild-caught females had gonadosomatic index (GSI) varying from 1.6 to $13.7 \%$ with four distinct stages of ovarian development:

- Stage I (immature): small basophilic oocytes (25$100 \mu \mathrm{m})$ were dominant in the ovarian tissue. Observation of the ovary through the exoskeleton was difficult. GSI values varied from 2.1 to $3.1 \%$. Ovary color ranged from translucent to creamy (Pantone 4545 PC);

- Stage II (developing): acidophilic yolky oocytes $(100-220 \mu \mathrm{m})$ were located on the periphery of the ovarian lobe. The ovary was clearly visible through the exoskeleton and GSI ranges between 4.1 and $4.9 \%$. A light green color was observed (Pantone 578 PC);

- Stage III (mature): large (220-340 $\mu \mathrm{m})$ acidophilic oocytes with cortical rods in the periphery of the cytoplasm were typical of this stage. The ovary occupied all the available space in the body cavity (GSI $=5.1-13.7 \%)$. Ovarian color turned into olive-brown (Pantone 5747 PC);

- Stage IV (spent): the presence of atretic oocytes was the major feature distinguishing its cell arrangement from that of stage I. Morphology and color of the ovaries were very similar from that of stage I. Values of GSI were within 1.6-2.4\%.

These four ovarian maturation stages were in accordance with previous studies (Worsmann et al., 1971; Worsmann and Sesso, 1977), which distinguished three different oocytes types distributed within four maturation stages. Therefore, it could be possible that some ovarian stages described previously based on ovarian color and/or morphology (Marchiori and Boff, 1983; Marchiori, 1996; D'Incao, 1999) might be macroscopic variations within a similar histological feature.

\section{MATURATION AND SPAWNING}

Several factors must be managed to ensure the success of maturation and mating of penaeids under laboratory conditions (Bray and Lawrence, 1992; Browdy, 1992; Browdy, 1998). Marchiori (1996) summarized the basic procedures and technologies for the maturation and spawning of $F$. paulensis in captivity. More information can be found in other studies on controlled reproduction 
(Marchiori and Boff, 1983; Muedas and Beltrame, 1991; Beltrame and Andreatta, 1993; Marchiori and Cavalli, 1993; Vinatea et al., 1993; Cavalli et al., 1997; Cavalli et al., 1998; Peixoto et al., 2002b; Peixoto et al., 2003b,c; Peixoto et al., 2004a,b).

Since closed thelycum females mate once per molt cycle, the number of males may be reduced in an attempt to optimize production by increasing the number of females per unit area in maturation tanks. Therefore, male to female ratios ranging from 1:1 to $1: 1.5$ and stocking densities from 5 to 7 animals $/ \mathrm{m}^{2}$ have been commonly employed for $F$. paulensis. Poor mating success was also associated with the small size of experimental maturation tanks (Peixoto et al., 2003c). However, descriptions of mating behavior for this species suggested that tank size did not play a significant role as females tended to stay on the bottom and did not swim before and during copulation (Brisson, 1985). Reis et al. (1998) found no significant differences in the hatching rate of $F$. paulensis broodstock kept in 2.5 or $4 \mathrm{~m}$ diameter maturation tanks.

Individual performance of females stocked in maturation tanks can be easily tracked through simple tagging systems. The use of colored silicone rings in the remaining eyestalk was previously described for ablated females of $F$. paulensis by Tsuzuki et al. (1993). The silicone ring must be of an appropriate diameter to avoid either losing the ring or strangling the eyestalk. Therefore, the authors recommended an internal diameter of $3 \mathrm{~mm}$ for females between 20 and $70 \mathrm{~g}$.

Generally high water exchange rates (100-400\% /day) are adopted in the maturation of penaeids (Bray and Lawrence, 1992), mainly to reduce the levels of nitrogenous compounds. However, since no significant effects of ammonia on molting and reproductive performance of $F$. paulensis were detected under long-term exposure, low water exchange rate $(50 \%)$ has been recommended to reduce labor and costs, as well as to maintain stable environmental conditions (Cavalli et al., 1998). Other environmental conditions applied for $F$. paulensis maturation include artificial photoperiod (12-14 h/day), water temperature varying from 25 to $29^{\circ} \mathrm{C}$ and full seawater salinity. Broodstock feeding is usually based on low proportions of commercial maturation diets and a mixture of fresh frozen marine organisms including shrimp (Artemesia longinaris), squid (Illex sp.), fish (various species), mussel (Perna sp.) and crab (Callinectes sp.) offered in four or five daily portions. Live olygochaeta (Eisenia sp.) have also been fed and though neither its biochemical composition nor its value was experimentally investigated, we observed that they were eagerly consumed by $F$. paulensis breeders. Proper spawning tank size, hygiene and water quality are also important for maximizing the number and quality of nauplii produced per spawn. Usually females with ripe ovaries are transferred daily to separate spawning tanks with water volume ranging from 90 to 120 liters. The total number of eggs is estimated from samples of the spawning tank water and fertilization rate is determined microscopically. Additionally, a disinfection protocol adapted from Brock and Main (1994) has been applied to avoid the presence of undesirable microorganisms attached to the surface of the eggs, as well as to remove eventual fragments of feces and ovarian tissue frequently observed in the spawning tank water. This protocol consists basically in six steps, as follows: 1) concentrate the eggs using a $120 \mu \mathrm{m}$ mesh collector (4 liters) with aeration; 2) wash the eggs gently for 1 minute using seawater at the same temperature and salinity; 3) add $1 \mathrm{ml}$ of formalin $(37 \%)$ in the collector for 30 seconds; 4) repeat step $2 ; 5)$ add $1 \mathrm{ml}$ of iodine $(20 \mathrm{ppm})$ in the collector for 30 seconds; 6) repeat step 2.

The eggs are then transferred to incubation tanks with similar water temperature and salinity. Reis et al. (1998) reported that hatching rates of $F$. paulensis were not affected by the volume (40 and 90 1) of the incubation tanks. Generally, at temperatures around $25-26{ }^{\circ} \mathrm{C}$, the eggs start to hatch after 15-16 hours from spawning (Marchiori, 1996).

\section{ARTIFICIAL INSEMINATION}

The lack of mating in maturation tanks is usually linked to the absence of fertile spawns (Beard and Wickins, 1980; Lin and Ting, 1986; Peeters and Diter, 1994). Similarly, a decrease in the fertilization rates of wild $F$. paulensis broodstock has been related to the lack of mating in maturation tanks, causing significant losses in nauplii production (Peixoto et al., 2004a). In closed thelycum penaeids, artificial insemination must be done soon after molting, while the female exoskeleton is still soft and the spermatophore can be easily implanted into the seminal receptacle 
without causing injuries (Lin and Ting, 1986). Therefore, daily assessment of females is essential to identify those that have recently molted. Simple methods to recognize exuviae in the tanks is establishing a code by clipping the uropods of each female or gluing a numbered tag on the exoskeleton (Peixoto et al., 2003c; Peixoto et al., 2004a).

The first successful attempt to artificially inseminate $F$. paulensis females was performed by Petersen et al. (1996), who found similar spawning performance using naturally mated and artificially inseminated females. The efficiency of artificial insemination to overcome the lack of mating and improve the reproductive performance of $F$. paulensis was also compared in conventional versus unisex maturation systems (Peixoto et al., 2004a). This study indicated that the presence or absence of males had no effect on the reproductive performance of artificially inseminated females. It might also be possible to optimize the maturation facilities and management by holding $F$. paulensis females separately from males.

The spermatophores could be extruded manually by gently pressing around the coxae of the fifth pair of pereiopods (Petersen et al., 1996). Practical experience indicated the ease of use and lesser injuries with electrical extrusion of spermatophores. The use of one spermatophore to artificially inseminate $F$. paulensis females proved enough to fertilize three successive spawns with no decrease in hatching rates (Peixoto et al., 2004a). Similarly, hatching rates for the first and second spawns were reported for $F$. paulensis inseminated with either one (70.6 to $78.3 \%$, respectively) or two halves (71 to $73 \%$ ) of spermatophore as well as with naturally mated females (80 to 83\%) (Petersen et al., 1996). These results reinforced the notion that the number of $F$. paulensis males required as sperm donors for artificial insemination could be minimized by using one spermatophore per female.

\section{REPRODUCTIVE PERFORMANCE}

Although many advances in the development of maturation and reproduction of $F$. paulensis have been made, the unpredictability and the high costs associated with the capture of wild broodstock in deep-sea waters $(40-60 \mathrm{~m})$ remain a major bottleneck. In the last few years, due to lower costs, animals have also been captured in shallow water $(5-10 \mathrm{~m})$ bays of Florianópolis, SC. Although presenting an acceptable spawning performance (Peixoto et al., 2003b), a marked decrease in egg quality and nauplii survival has been observed when using animals from this source (Peixoto et al., 2002b). Therefore, recent studies have focused to improve reproductive performance and offspring quality of captive $F$. paulensis broodstock, as a future alternative for a more independent and reliable nauplii production (Cavalli et al., 1997; Peixoto et al., 2003b; Peixoto et al., 2004b).

The reproductive performance of penaeids is known to be affected by broodstock source and size (Browdy et al., 1986; Menasveta et al., 1993; Ramos et al., 1995). The size recommended for the reproduction of $F$. paulensis females in captivity ranged from 30 to $60 \mathrm{~g}$ (Bueno, 1989; Cavalli et al., 1997). Previous studies indicated a higher egg and nauplii production for deep-sea caught $F$. paulensis broodstock compared to animals from shallow waters (Beltrame and Andreatta, 1991), ponds (Beltrame and Andreatta, 1991; Cavalli et al., 1997) and estuaries (Marchiori and Cavalli, 1993). However, since a positive relationship between female size and fecundity has been demonstrated for $F$. paulensis (Cavalli et al., 1997; Peixoto et al., 2004b), the reliability of these differences in reproductive performance is questionable due to size discrepancies between the different experimental groups. When similarlysized $F$. paulensis broodstock from different sources were compared a greater number of eggs/spawn (78.414) and higher total egg production $(4,469,600)$ were recorded for the wild females $(31.7 \mathrm{~g})$, but captive females (32.9 g) produced more nauplii $(1,788,259)$ as a result of a higher percentage of fertilized spawns (Peixoto et al., 2003b).

Several studies conducted under similar maturation conditions reported mean number of eggs/spawning event of deep-sea $F$. paulensis varying from 100,000 to 160,000 and fertilization rates higher than 65\% (Marchiori and Cavalli, 1993; Cavalli et al., 1997; Cavalli et al., 1998; Peixoto et al., 2004a). Although Peixoto et al. (2003b) found 78,000 eggs/spawning event and mean fertilization of $68.4 \%$ to be acceptable for shallow water $F$. paulensis, low offspring viability has been observed using this broodstock source. It has been suggested that $F$. paulensis females captured in shallow waters are not able to attain full oocyte development (absence of cortical rods), 
which might be related to their poor offspring quality (Peixoto et al., 2002b). Nevertheless, promising results on ovarian maturation, overall spawning performance and offspring viability were recently reported for captive $F$. paulensis overwintered indoors (Peixoto et al., 2004b).

Although it has been generally accepted that larger, presumably older $F$. paulensis females present a superior spawning performance, the influence of age on wild broodstock has not been thoroughly examined. The effect of size, rather than age, on the productivity of $F$. paulensis was previously reported by Cavalli et al. (1997). In accordance, Peixoto et al. (2004b) working with two size classes (small and large) at the same age (10- and 16-month-old groups) of captive $F$. paulensis broodstock, found evidence that larger females (25.8 and $46.7 \mathrm{~g}$ for 10- and 16-month-old groups, respectively) presented a superior reproductive performance in terms of number of spawns, spawning frequency and egg production/female. Studies on age-pigment lipofuscin in $F$. paulensis brains may provide a future alternative for age estimations and association with reproductive performance of wild shrimp at different ages (Peixoto et al., 2002c).

Sexual maturity of wild and captive $F$. paulensis males is known to occur at an early stage (Costa, 1992). Marchiori and Cavalli (1993) found no differences in egg hatching rates in relation to the size of pond-reared (19 g) and wild $F$. paulensis males $(25 \mathrm{~g})$. Regardless the source, males with body weight over $16 \mathrm{~g}$ have been recommended for controlled reproduction purposes (Cavalli et al., 1997). The sexual capability of males of this size was confirmed for captive 10-month-old $F$. paulensis males based on sperm quality and hatching performance (Peixoto et al., 2004b). However, smaller 10-month-old males (10 g) also showed acceptable sperm quality, but further studies would be needed to evaluate the mating success of these males when paired with larger/older females.

\section{BROODSTOCK MANAGEMENT}

Indoor facilities have been used for overwintering broodstock in temperate regions, which is crucial to close the life cycle of penaeids in such areas (Browdy, 1992). In southern Brazil $\left(32^{\circ} \mathrm{S}\right)$, where low water temperatures do not allow broodstock culture in outdoor ponds during winter, a raceway system enclosed in greenhouse has been used to culture juveniles to broodstock size (Peixoto et al., 2001; Peixoto et al., 2003b; Peixoto et al., 2004b). In this system, a continuous recirculation system containing a 1,000-liter biological filter provides two turnovers/day in two $22 \mathrm{~m}^{3}$ culture tanks. Seawater is exchanged at a rate of $3 \% / \mathrm{d}$. Water temperature is maintained above $20^{\circ} \mathrm{C}$ by submerged heaters. Nitrogenous compounds (e.g. total ammonia and nitrite), $\mathrm{pH}$, and salinity are analyzed weekly. Stocking densities are usually limited to $7 \mathrm{shrimp} / \mathrm{m}^{2}$ and male to female ratio ranging from $1: 1.5$ to $1: 2$. Animals are fed to satiation once a day $(17,00 \mathrm{~h})$ alternating fresh frozen crab (Callinectes sp.), squid (Illex sp.), shrimp (Artemesia longinaris), fish (several species) and a commercial maturation diet.

The von Bertalanffy model was used to represent weight growth of $F$. paulensis broodstock during the raceway culture in extreme southern Brazil, as follows (Peixoto et al., 2001):

$$
\begin{aligned}
& \mathrm{W}_{\mathrm{t}}=42.39\left[1-\mathrm{e}^{-1.15(\mathrm{t}+0.0442)}\right]^{2.501} \text { (males) } \\
& \mathrm{W}_{\mathrm{t}}=55.74\left[1-\mathrm{e}^{-1.57(\mathrm{t}-0.0036)}\right]^{2.517} \text { (females) }
\end{aligned}
$$

where $\mathrm{W}_{\mathrm{t}}$ is body weight at time $\mathrm{t}$ (years).

Under controlled environmental conditions, the minimal broodstock size for $F$. paulensis was attained after approximately nine months for wild juveniles captured in the Patos Lagoon estuary (Peixoto et al., 2001; Peixoto et al., 2003b) and after ten months for captive juveniles obtained from pen culture in the same estuary (Peixoto et al., 2004b). Nevertheless, significant improvements on reproductive output were achieved by using larger $F$. paulensis broodstock (30.2 and $46.7 \mathrm{~g}$ for males and females, respectively) reared for 16 months in the same raceway system (Peixoto et al., 2004b).

\section{CONSTRAINTS AND PERSPECTIVES}

Despite the importance of shrimp broodstock nutrition, little information is available on the role of different nutrients during maturation and reproduction (Harrison, 1990; Harrison, 1997; Wouters et al., 2001). Fresh frozen feeds supplemented with high quality artificial maturation diets have resulted in acceptable reproduction output of $F$. paulensis, but no attempt 
to identify specific nutrient requirements has been proposed for this species. Studies to examine the relationship between nutritional requirements and reproductive performance of $F$. paulensis should be given more attention.

Although the use of artificial insemination may help to overcome the lack of mating for $F$. paulensis in captivity, little is known about the cause of this problem. Whatever be the cause, the maturation system and broodstock should be thoroughly checked before stocking the breeders in order to prevent the lack of mating. Topics to be checked include: environmental and physical conditions, feed and feeding schedules, overall health and condition of the broodstock, husbandry practices and other routine procedures. Further studies are necessary to identify the possible factors affecting the mating success of $F$. paulensis in captivity.

Genetics and biotechnology in penaeids have been reviewed (Benzie, 1997; Benzie, 1998) and selective breeding programs have been successfully achieved for some species (PérezRostro and Ibarra, 2003; Le Moullac et al., 2003; Li et al., 2003). Current efforts to close the life cycle and improve reproductive performance of $F$. paulensis in captivity would hopefully be able to design an efficient breeding program through the selection of desirable characteristics reflected in culture performance.

The future success of $F$. paulensis culture in extreme southern Brazil would depend upon increasing supplies of high quality seed for stocking farm ponds and pens. Unfortunately, the current reliance on nauplii derived from wild broodstock could constrain the long term sustainability in the region. New challenges, associated especially with the nutritional requirements during the growout phase and the development of genetically improved captive broodstock, must be achieved through research efforts in the private and public sectors.

\section{RESUMO}

Esta revisão constitui a primeira iniciativa de reunir em um só documento os recentes desenvolvimentos/estudos sobre maturação e reprodução de Farfantepenaeus paulensis em cativeiro. O objetivo do presente estudo foi revisar informações que poderão colaborar para a produção sustentável de náuplios de $F$. paulensis em cativeiro. Foi dada ênfase aos estudos que vem sendo realizados na última década no Laboratório de Maricultura, Fundação Universidade Federal do Rio Grande, RS. A discussão aborda aspectos relativos ao ciclo reprodutivo, maturação ovariana, sistemas de maturação e desova, inseminação artificial, performance de reprodutores e manutenção de reprodutores em cativeiro.

\section{REFERENCES}

Ayub, Z. and Ahmed, M. (2002), A description of the ovarian development stages of penaeid shrimps from the coast of Pakistan. Aquaculture Research, 33, 767-776.

Beard, T. W. and Wickins, J. F. (1980), Breeding of Penaeus monodon Fabricius in laboratory recirculation systems. Aquaculture, 20, 79-89.

Beltrame, E. and Andreatta, E. R. (1991), Maturação em cativeiro do camarão-rosa, Penaeus paulensis PérezFarfante, 1967 - Estudo sobre a origem dos reprodutores. In: Encontro Nacional de Pesca e Aqüicultura, Santos. Anais... Santos, Brazil.

Beltrame, E. and Andreatta, E. R. (1993), Importancia del periodo de adaptacion y performance individual de hembras de Penaeus paulensis (Pérez-Farfante, 1967) en el proceso de maduración en cautiverio. In: Congresso Latinoamericano de Ciencias del Mar, Coquimbo, Chile. Anais... Chile.

Benzie, J. A. H. (1997), A review of the effect of genetics and environment on the maturation and larval quality of the giant tiger prawn Penaeus monodon. Aquaculture, 155, 69-85.

Benzie, J. A. H. (1998), Penaeid genetics and biotechnology. Aquaculture, 164, 23-47.

Bray, W. A. and Lawrence, A. L. (1992), Reproduction of Penaeus species in captivity. In: Fast, A. W. and Lester, J. L. (Eds.). Marine Shrimp Culture: principle and practices. Elsevier, Netherlands. pp. 93-170.

Brisson, S. (1985), The mating behavior of Penaeus paulensis Pérez-Farfante, 1967 (Decapoda, Penaeidae). Crustaceana, 50, 108-110.

Brock, J. A. and Main, K. L. (1994), A guide to the common problems and diseases of cultured Penaeus vannamei. Louisiana, USA: The World Aquaculture Society, Baton Rouge.

Browdy, C. L. (1992), A review of the reproductive biology of Penaeus species: perspectives on controlled shrimp maturation systems for high quality nauplii production. In: Wyban, J. (Ed.). Proceedings of the Special Session on Shrimp Farming. Florida, USA. pp.22-51.

Browdy, C. L. (1998), Recent developments in penaeid broodstock and seed production technologies: improving the outlook for superior captive stocks. Aquaculture, 164, 3-21. 
Browdy, C. L.; Hadani, A.; Samocha, T. M., and Loya, Y. (1986), The reproductive performance of wild and pond-reared Penaeus semisulcatus de Haan. Aquaculture, 49, 251-258.

Bueno, S. L. S. (1989), Técnicas, procedimentos $e$ manejos para a produção de pós-larvas de camarões peneídeos. CIRM, Brasília, Brazil.

Cavalli, R. O.; Scardua, M. P. and Wasielesky, W. (1997), Reproductive performance of different-sized wild and pond-reared Penaeus paulensis females. Journal of the World Aquaculture Society, 28, 260-267.

Cavalli, R. O.; Peixoto, S. M. and Wasielesky, W. (1998), Performance of Penaeus paulensis (PérezFarfante) broodstock under long-term exposure to ammonia. Aquaculture Research, 29, 815-822.

Costa, S. W. (1992), Aspectos da biologia da reprodução de machos do "Camarão-Rosa" Penaeus (Farfantepenaeus) paulensis Pérez-Farfante, 1967 (Crustacea, Decapoda, Penaeidae) para o manejo de reprodutores em aqüicultura. Masters Thesis, Universidade Federal de Santa Catarina. 121 pp.

Dall, W.; Hill, B. J.; Rothlisberg, P. C. and Staples, D. J. (1990), The Biology of the Penaeidae. Advances in Marine Biology. London: Academic Press.

D'Incao, F. (1991), Pesca e biologia de Penaeus paulensis na Lagoa dos Patos, RS. Atlântica, 13, 159-169.

D'Incao, F. (1999), Subordem Dendrobranchiata (Camarões Marinhos). In: Buckup, L. and BondBuckup, G. (Ed.). Os Crustáceos do Rio Grande do Sul. Porto Alegre, Brazil. pp.275-299.

D'Incao, F. and Reis, E. G. (2002), Community-based management and technical advice in Patos Lagoon estuary (Brazil). Ocean and Coastal Management, 45, 531-539.

Harrison, K. E. (1990), The role of nutrition in maturation, reproduction and embryonic development of decapod crustaceans: a review. Journal of Shellfish Research, 9, 1-28.

Harrison, K. E. (1997), Broodstock nutrition and maturation diets. In: D’Abramo, L. R., Conklin, D. E. and Akiyama, D.M. (Ed.). Crustacean nutrition. Advances in World Aquaculture. Baton Rouge: The World Aquaculture Society. pp. 390-408.

Huberman, A. (2000), Shrimp endocrinology. A review. Aquaculture, 191, 191-208.

Le Moullac, G.; Goyard E.; Saulnier, D.; Haffner, P.; Thouard, E.; Nedelec, G.; Goguenheim, J.; Rouxel, C.; Cuzon, G. and Aquacop (2003), Recent improvements in broodstock management and larviculture in marine species in Polynesia and New Caledonia: genetic and health approaches. Aquaculture, 227, 89-106.

Li, Y.; Byrne, K.; Miggiano, E.; Whan, V.; Moore, S.; Keys, S.; Crocos, P.; Preston, N. and Lehnert. S. (2003), Genetic mapping of the kuruma prawn Penaeus japonicus using AFLP markers. Aquaculture, 219, 143-156.
Lin, M. and Ting, Y. (1986), Spermatophore transplantation and artificial fertilization in Grass Shrimp. Bulletin of the Japanese Society of Scientific Fisheries, 52, 585-589.

Marchiori, M. A. (1996), Guia ilustrado de maturação e larvicultura do camarão-rosa Penaeus paulensis Pérez-Farfante, 1967. FURG, Rio Grande, Brazil.

Marchiori, M. A. and Boff, M. H. (1983), Induced maturation, spawning and larvae culture of the pink shrimp Penaeus paulensis Pérez-Farfante, 1967. Memorias Asociación Latinoamericana Acuicultura, 5, 331-337.

Marchiori, M. A. and Cavalli, R. O. (1993), Commercial scale maturation of Penaeus paulensis in a semi-closed recirculation system. In: Symposium on Shrimp Culture, 4., João Pessoa. Anais... João Pessoa, Brazil

Medina, A.; Vila, Y.; Mourente, G. and Rodrígues, A. (1996), A comparative study of the ovarian development in wild and pond-reared shrimp, Penaeus kerathurus (Forskal, 1775). Aquaculture, 148, 63-75.

Menasveta, P.; Piyatiratitivorakul, S.; Rungsurpa, S.; Moree, N. and Fast, A. W. (1993). Gonadal maturation and reproductive performance of giant prawn (Penaeus monodon Fabricius) from the Andaman Sea and pond-reared sources in Thailand. Aquaculture, 116, 191-198.

Muedas, W. and Beltrame, E. (1991), Influencia de la alimentacíon en reproductores de Penaeus paulensis (Perez-Farfante, 1967), considerando su efecto en la produccíon de nauplios. In: Congresso LatinoAmericano de Aquacultura, 4., Coquimbo. Anais... Coquimbo, Chile.

Ogle, J. T. (1992), A review of the current (1992) state of our knowledge concerning reproduction in open thelycum penaeid shrimp with emphasis on Penaeus vannamei. Invertebrate Reproduction and Development, 22, 267-274.

Palacios, E.; Rodríguez-Jaramillo, C. and Racotta, I. S. (1999), Comparison of ovary histology between different-sized wild and pond-reared shrimp Litopenaeus vannamei (=Penaeus vannamei). Invertebrate Reproduction and Development, 35, 251-259.

Peeters, L. and Diter, A. (1994), Effects of impregnation on maturation, spawning, and ecdysis of female shrimp Penaeus indicus. Journal of Experimental Zoology, 269, 522-530.

Peixoto, S.; D'Incao, F.; Wasielesky, W. and Poersch, L. H. (1998), Análise da viabilidade reprodutiva do camarão-rosa Penaeus paulensis em laboratório sem a utilização da técnica de ablação do pedúnculo ocular de fêmeas. In: Reunião Anual do Instituto de Pesca, 7., São Paulo. Anais... São Paulo.

Peixoto, S.; D'Incao, F. and Wasielesky, W. (2001), Application of von Bertalanffy growth curves in a Farfantepenaeus paulensis (Decapoda, Penaeidae) captive broodstock. Nauplius, 9, 149-155. 
Peixoto, S.; Cavalli, R. O.; D’Incao, F.; Wasielesky, W. and Milach, Â. (2002a), A comparative study of the ovarian histology of eyestalk ablated and unablated Farfantepenaeus paulensis after spawning. Boletim do Instituto de Pesca, 28, 71-76.

Peixoto, S.; Cavalli, R. O.; D’Incao, F.; Wasielesky, W. and Aguado, N. (2002b), Description of reproductive performance and ovarian maturation of wild Farfantepenaeus paulensis from shallow waters in southern Brazil. Nauplius, 10, 149-153.

Peixoto, S.; Aguado, N.; D'Incao, F.; Wasielesky, W. and Cousin, J. C. (2002c), Preliminary identification and quantification of the age-pigment, lipofuscin, in the brain of Penaeus paulensis (Crustacea: Decapoda). Brazilian Journal of Biology, 62, 871-876.

Peixoto, S.; Wasielesky, W. and Louzada, L. (2003a), Comparative analysis of pink shrimp, Farfantepenaeus paulensis, and Pacific white shrimp, Litopenaeus vannamei, culture in extreme southern Brazil. Journal of Applied Aquaculture, 14, 101-111.

Peixoto, S.; Wasielesky, W.; D'Incao, F, and Cavalli, R. O. (2003b), Reproductive performance of similarly-sized wild and captive Farfantepenaeus paulensis. Journal of the World Aquaculture Society, 34, 50-56.

Peixoto, S.; Cavalli, R. O. and Wasielesky, W. (2003c), The influence of water renewal rates on the reproductive and molting cycles of Penaeus paulensis in captivity. Brazilian Archives of Biology and Technology, 46, 281-286.

Peixoto, S.; Cavalli, R. O.; D'Incao, F.; Milach, Â. and Wasielesky, W. (2003d), Ovarian maturation of wild Farfantepenaeus paulensis in relation to histological and visual changes. Aquaculture Research, 34, 1255-1260.

Peixoto, S.; Cavalli, R. O.; Krummenauer, D.; Wasielesky, W. and D'Incao, F. (2004a), Influence of artificial insemination on reproductive performance of Farfantepenaeus paulensis in conventional and unisex maturation systems. Aquaculture, 230, 197-204.

Peixoto, S.; Cavalli, R. O.; Wasielesky, W.; D’Incao, F.; Krummenauer, D. and Milach, Â. (2004b), Effects of age and size on reproductive performance of captive Farfantepenaeus paulensis broodstock. Aquaculture, 238, 173-182.

Pérez-Farfante, I and Kensley, B. (1997), Penaeoid and sergestoid shrimps and prawns of the world. Keys and diagnoses for the families and genera. Éditions du Muséum national d'Histoire naturelle, Paris.

Pérez-Rostro, C. I. and Ibarra, A. M. (2003), Quantitative genetic parameter estimates for size and growth rate traits in Pacific white shrimp, Penaeus vannamei (Boone 1931) when reared indoors. Aquaculture Research, 34, 543-553.

Petersen, R. L.; Beltrame, E. and Derner. R. (1996), Inseminaçion artificial en Penaeus paulensis PérezFarfante, 1967. Revista de Investigaciones Marinas, 17, 215-219.
Quinitio, E. T.; Caballero, R. M. and Gustilo, L. (1993), Ovarian development in relation to changes in the external genitalia in captive Penaeus monodon. Aquaculture, 114, 71-81.

Ramos, L.; Espejo, M.; Samada, S. and Pérez, L. (1995), Maturation and reproduction of pond-reared Penaeus schmitti. Journal of the World Aquaculture Society, 26, 183-187.

Reis, E. G. and D'Incao, F. (2000), The present status of artisanal fisheries of extreme Southern Brazil: an effort towards community-based management. Ocean and Coastal Management, 43, 585-595.

Reis, M. A.; Beltrame, E.; Petersen, R. and Portillo, G. (1998), Reprodução em cativeiro do "camarão rosa" Penaeus paulensis (Pérez Farfante, 1967): estudo comparativo de diferentes sistemas de maturação, desova e eclosão. In: Aquicultura Brasil 98, Recife. Anais... Recife, Brasil.

Tan-Fermin, J. D. and Pudadera, R. A. (1989), Ovarian maturation stages of the wild giant tiger prawn Penaeus monodon Fabricius. Aquaculture, 77, 229-242.

Tsuzuki, M. Y.; Zimmermann, S.; Cavalli, R. O. and Marchiori, M. A. (1993), A utilização de aneis de silicone como identificadores em camarões In: Symposium on Shrimp Culture, 4., João Pessoa. Anais... João Pessoa, Brazil.

Vinatea, L.; Olivera, A.; Andreatta, E.; Beltrame, E.; Petersen, R. and Derner, R. (1993), Producción comercial de larvas de Penaeus paulensis y Penaeus schmitti en el sur del Brasil. In: Symposium on Shrimp Culture, 4., João Pessoa. Anais... João Pessoa, Brazil.

Wasielesky, W.; Poersch, L. H.. and Bianchini, A. (1999), Comparação entre a sobrevivência e o crescimento do camarão rosa Farfantepenaeus paulensis cultivado em gaiolas e cercados. Nauplius, 7, 173-177.

Wasielesky, W.; Poersch, L. H..; Jensen, L. V. and Bianchini, A. (2001), Effect of stocking density on growth of pen reared pink shrimp Farfantepenaeus paulensis (Pérez-Farfante, 1967) (Crustacea, Penaeidae). Nauplius, 9, 163-167.

Worsmann, T. U.; Neiva, G. S.; Oliveira, M. T. and Valentini, H. (1971), Contribuição ao estudo da maturação da gônada feminina do "camarão-rosa" (Penaeus paulensis Perez Farfante, 1967). Boletim do Instituto de Pesca, 1, 23-28.

Worsmann, T. U. and Sesso, A. (1977), Observations ultrastructurales sur la maturation des cellules germinales de l'ovaire de Penaeus paulensis. Archives D'Anatomie D'Histologie D'Embryologie Normales et Expérimentales, 60, 175-188.

Wouters, R.; Lavens, P.; Nieto, J. and Sorgeloos, P. (2001), Penaeid shrimp broodstock nutrition: an updated review on research and development. Aquaculture, 202, 1-21. 
Zenger, H. H. and Agnes, J. L. (1977), Distribuição do camarão-rosa (Penaeus brasiliensis e Penaeus paulensis) ao longo da costa sudeste e sul do Brasil. Serie Documentos Técnicos SUDEPE-PDP, 21, 1-10.

Received: April 19, 2004; Revised: July 29, 2004; Accepted: March 04, 2005. 